\title{
Automatic Milking Systems in the Production of Parmigiano Reggiano Cheese: Effects on the Milk Quality and on Cheese Characteristics
}

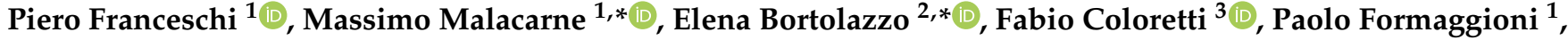 \\ Anna Garavaldi ${ }^{2}$, Valeria Musi ${ }^{2}$ and Andrea Summer ${ }^{1}$ (D) \\ 1 Department of Veterinary Science, University of Parma, Via del Taglio 10, 43126 Parma, Italy; \\ piero.franceschi@unipr.it (P.F.); paolo.formaggioni@unipr.it (P.F.); andrea.summer@unipr.it (A.S.) \\ 2 Centro Ricerche Produzioni Animali, Viale Timavo 43/2, 42121 Reggio Emilia, Italy; \\ a.garavaldi@crpa.it (A.G.); v.musi@crpa.it (V.M.) \\ 3 Department of Agricultural and Food Sciences, University of Bologna, Via Giuseppe Fanin 50, 40127 Bologna, \\ Italy; fabio.coloretti2@gmail.com \\ * Correspondence: massimo.malacarne@unipr.it (M.M.); e.bortolazzo@crpa.it (E.B.) \\ Tel.: +39-0521-032-615 (M.M.); +39-0522-436-999 (E.B.)
}

Citation: Franceschi, P.; Malacarne, M.; Bortolazzo, E.; Coloretti, F.;

Formaggioni, P.; Garavaldi, A.; Musi, V.; Summer, A. Automatic Milking Systems in the Production of Parmigiano Reggiano Cheese: Effects on the Milk Quality and on Cheese Characteristics. Agriculture 2022, 12, 104. https://doi.org/10.3390/ agriculture12010104

Academic Editor: Senaka

Ranadheera

Received: 17 December 2021

Accepted: 10 January 2022

Published: 12 January 2022

Publisher's Note: MDPI stays neutral with regard to jurisdictional claims in published maps and institutional affiliations.

Copyright: (c) 2022 by the authors. Licensee MDPI, Basel, Switzerland. This article is an open access article distributed under the terms and conditions of the Creative Commons Attribution (CC BY) license (https:// creativecommons.org/licenses/by/ $4.0 /)$.

\begin{abstract}
The adoption of innovative processes, such as the automatic milking system (AMS), in the production of typical PDO cheeses, such as Parmigiano Reggiano, needs to be evaluated and tested, to verify its influence on milk quality and the typicality of the product. The present research was aimed to study the effect of the introduction of the AMS on the cheesemaking characteristics of the milk and the ripening process and the sensory properties of the Parmigiano Reggiano PDO cheese. Six cheesemaking trials were performed and, in each trial, two different separated pools of milk were submitted to the cheesemaking process in parallel, one from AMS and the other from a traditional milking parlor (TMP). AMS milk, in comparison with TMP one, showed higher content of lactose and calcium and lower contents of somatic cells, thermophilic lactic acid bacteria and chloride. Nevertheless, these changes were too small to influence the efficiency of the cheesemaking process and the cheese composition and its sensory profile. Moreover, cheeses made with AMS milk fully complied with the sensory characteristics of Parmigiano Reggiano cheese PDO, as defined by the PDO rules.
\end{abstract}

Keywords: automatic milking; Parmigiano Reggiano cheese; cheese quality; milk quality

\section{Introduction}

Parmigiano Reggiano cheese is a Protected Designation of Origin cheese ripened for a period of a minimum of 12 months but that can also be extended over 24 months.

Parmigiano Reggiano PDO cheese is a hard-cooked cheese, and it is made starting from partially-skimmed raw bovine milk, following a strict manufacturing protocol.

Nowadays, milking is the most important operation that takes place on farms, and it takes up most of the labour. Moreover, the milking is heavy work and, at the same time, must be done by specialised workers. Consequently, milking has a high cost both in economic and social terms [1].

Since it is hard work, during the last years there has been a shortage of labour as a consequence of a large decrease in the number of milkers. A solution to this problem could be the automatic milking systems [2,3], which are now diffused in large farms of Europe [4].

However, the diffusion of the use of automatic milking systems in the farms producing milk for Parmigiano Reggiano is slow, since the adoption of innovative processes, such as AMS, in the production of typical PDO cheeses, such as Parmigiano Reggiano, needs to be evaluated and tested to verify its influences on milk quality and the typicality of the product. 
From this point of view, the use of automatic milking systems can affect both milk chemical composition [5] and milk physicochemical properties [4]. These changes mainly regard the decrease in milk fat and casein contents [1], which, in turn, could negatively influence both the cheese yield [6] and cheese-making efficiency [7].

However, the influence of automatic milking systems on these changes in milk characteristics is mainly due to the increase in the number of milkings per day that typically increase from two to three or more [4,5] but in the production of Parmigiano Reggiano, three daily milkings are not allowed. Indeed, the Parmigiano Reggiano production's regulations [8] specifies that the cows must be milked only twice a day, in the morning and the evening, and that from the start of milking to the delivery of the milk in the cheese factory cannot be more than $7 \mathrm{~h}$. Consequently, the AMS must only be switched on two times a day.

Moreover, several studies have examined the effect of the milking system on milk somatic cells count. The findings vary from reports that show that the use of an automatic milking system produces no changes or a decrease in somatic cell count $[1,5]$, to some others, that report increases in milk somatic cell count $[9,10]$.

Milk somatic cells count is one of the main parameters that define the quality of milk for Parmigiano Reggiano cheese. The increase in somatic cells, indeed, is related to a decrease in milk casein content and a worsening of milk physicochemical properties [11], which are associated with a decrease in cheese yield [12,13].

Furthermore, since the autochthonous lactic acid bacteria play a fundamental role in the production of a traditional PDO cheese [14] made from raw milk, due to their influence on the cheese proteolysis and lipolysis processes [14-16], the adoption of innovative processes in typical productions, such as that of Parmigiano Reggiano, must be evaluated and tested, to verify their effects on the lactic acid bacteria grow.

Therefore, the aim of the research was to study the effect of the milking system on the cheesemaking characteristics of the milk and the ripening process and the sensory properties of the Parmigiano Reggiano PDO cheese.

\section{Materials and Methods}

\subsection{Experimental Design, Sampling Procedure and Classification of Cheese Batches}

The research was performed operating in a mono-breed farm of Italian Friesian cows. On this farm, half of the cows were milked with an automatic milking system (AMS-milk), and the other half were milked into a traditional milking parlor (TMP-milk). The milk produced was then separately processed into Parmigiano Reggiano cheese.

One day a week during a period of six weeks, from March to April, two different separated pools of milk were produced during evening milking, one from AMS and the other from TMP. The day after, the same procedure was made for morning milking milk, and two samples of full cream milk (FC-milk), representative of the morning milking, were collected in parallel, one from the cooling tank of milk from cows milked by AMS, the other from the cooling tank of milk from cows milked by TMP.

At the dairy, naturally skimmed milk from the evening milking was mixed with whole milk from the morning milking maintaining the separation of AMS-milk from TMP-milk by using two different cheese vats.

Two samples of vat milk were collected, in parallel, one from vat milk (V-milk) obtained from the milk milked with AMS and the other from the vat milk obtained from the milk milked with TMP.

Eleven cheese wheels (6 from AMS-milk and 5 from TMP-milk) were obtained from milk milked with the two systems and they were identified and kept separately from the other cheese wheels of the dairy. After 15 months of ripening, the cheese wheels of the research were sampled, and, from each of them, one sample, representative of the whole cheese wheel, was obtained, and then grated for chemical and microbiological analyses.

Furthermore, from each cheese wheel, two samples of about $1.2 \mathrm{~kg}$ were taken for sensory analysis. 


\subsection{Cheese-Making Process}

Both the milk of evening and morning milking was collected, commingling and submitted to the cheese-making process according to the Parmigiano Reggiano cheesemaking regulations [8].

The milk of evening milking was collected and placed into the creaming tank. The morning after, the partially skimmed milk was extracted from the bottom of the creaming tank and placed into a vat and then the full cream milk of the morning milking was added to it. From this commingling, vat milk was obtained.

The vat milk submitted to transformation cheese was partially skimmed milk, with about $2.6 \mathrm{~g} / 100 \mathrm{~g}$ of fat and with fat to casein ratio of about 1-1.1.

Natural whey starter culture derived by natural fermentation of the whey from the cheese-making of the day before was then added into the vat (about $3 \mathrm{~L}$ for each $100 \mathrm{~kg}$ ). Then, vat milk was clotted with calf rennet $(3 \mathrm{~g} / 100 \mathrm{~kg}$ of milk; strength 1:120,000; Caglio Bellucci srl, Modena, Italia) at $33^{\circ} \mathrm{C}$. The coagulation occurred in about $10 \mathrm{~min}$, and, after 2 min of curd firming, the curd was broken into granules that were as large as a grain of rice, which were immediately cooked by increasing the temperature to $55^{\circ} \mathrm{C}$ in $12 \mathrm{~min}$. Subsequently, the curd particles were left to settle naturally on the bottom of the vat for about one hour, to form a cheese mass; during this time, the temperature decreased slowly from $55{ }^{\circ} \mathrm{C}$ to about $50{ }^{\circ} \mathrm{C}$. Then, the cheese mass was extracted, divided into two parts, and placed for $48 \mathrm{~h}$ in moulds to form two twin cheese wheels. Afterwards, the cheese wheels were placed in brine (saturated with sodium chloride), to be salted, for a period of 20 days, and subsequently, they were stored in the ripening room, where they remained for 15 months of ripening, until the sampling. The temperature of the room was between 16 and $18{ }^{\circ} \mathrm{C}$, and the value of relative humidity was $80 \%$.

\subsection{Milk and Cheese Chemical and Technological Analyses}

For each FC-milk and V-milk sample, total non-casein and nonprotein nitrogen fractions [17-19], respectively on milk, acid whey at $\mathrm{pH} 4.6$ and filtered whey obtained after the addition of trichloroacetic acid (TCA $120 \mathrm{~g} / \mathrm{L}$; Carlo Erba Reagents, Milan, Italy) to the milk, was determined by the Kjeldahl method. From these data, crude protein, casein, casein number and NPNx6.38 were calculated as described by Franceschi et al. [20].

In addition, for each FC-milk and V-milk sample, lactose and fat contents were determined by the mid-infrared method [21], using a MilkoScan FT 6000, (Foss Electric, Hillerød, Denmark). The values of $\mathrm{pH}$ and titratable acidity were measured for FC-milk and V-milk by a potentiometer and by the titration of $50 \mathrm{~mL}$ of milk with $0.25 \mathrm{~N}$ sodium hydroxide with the Soxhlet-Henkel method [22], respectively. Both parameters were determined with the Crison Compact Titrator D (Crison Instruments, Barcelona, Spain).

Furthermore, for each FC-milk and V-milk sample, rennet coagulation parameters, were determined using the Formagraph (Foss Electric, Hillerød Denmark) [22]. In brief, the clotting time $(\mathrm{r})$, curd firming time $\left(\mathrm{k}_{20}\right)$, and curd firmness $\left(\mathrm{a}_{30}\right)$, were determined at $35^{\circ} \mathrm{C}$, adding $0.2 \mathrm{~mL}$ rennet solution (diluted 1:100) into $10 \mathrm{~mL}$ of milk (title 1:19,000; Chr. Hansen, Corsico, MI, Italy) [23]. Somatic cells and total bacterial count were determined using the fluoro-optoelectronic method [24], with the Fossomatic (Foss Electric, Hillerød, Denmark) and by the flow cytometry method with the BactoScan FC (Foss Electric, Hillerød, Denmark), respectively.

Dry matter and ash contents were obtained after oven drying at $102{ }^{\circ} \mathrm{C}$ of milk [25] and after muffle calcination at $530{ }^{\circ} \mathrm{C}$ of dried milk for FC-milk samples only [26], respectively.

Moreover, each FC-milk sample was skimmed by centrifugation and submitted to an ultrafiltration process in Amicon 8200 ultrafiltration cells (Merck Millipore Corporation, Darmstadt, Germany). The ultrafiltration process was performed as described by Malacarne et al. [27].

Furthermore, starting from ash solubilised in hydrochloric acid, total $\mathrm{Ca}$ and $\mathrm{Mg}$ from the milk ash solution, and soluble $\mathrm{Ca}$ and $\mathrm{Mg}$ from the ultrafiltration permeate ash solution were determined by Atomic Absorption Spectrometry (Perkin-Elmer 1100 B, Waltham, MA, 
USA) [28]. Total P and soluble P were assessed with the colourimetric method [28] for the milk ash solution and ultrafiltration permeate ash solution, respectively. From these values, the distribution of $\mathrm{Ca}, \mathrm{P}$ and $\mathrm{Mg}$ fractions was calculated according to Malacarne et al. [29] as follows:

$$
\mathrm{CMC}=\mathrm{TMC}-\mathrm{SMC}
$$

where $\mathrm{CMC}$ is the colloidal mineral content of $\mathrm{Ca}, \mathrm{P}$ or $\mathrm{Mg}, \mathrm{TMC}$ is the total mineral content and SMC is the soluble mineral content (all expressed in $\mathrm{mg} / 100 \mathrm{~g}$ ).

For FC-milk, chloride content was also determined, by titration with silver nitrate $\left(\mathrm{AgNO}_{3}\right)$ using the volumetric method of Charpentier-Volhard [30].

For cheese samples, total nitrogen (TN) [17] and soluble nitrogen at pH 4.4 (SN) were determined by the Kjeldahl method, as reported by Gripon et al. [31]. From these nitrogen fractions, the values of crude protein $(\mathrm{TN} \times 6.38)$ and the ripening index $(\mathrm{NS} \times 100 / \mathrm{TN})$ were calculated.

In addition, for cheese samples, dry matter and ash contents were obtained in the same way as for milk, i.e., after oven drying the cheese at $102{ }^{\circ} \mathrm{C}$ [25] and after muffle calcination at $530{ }^{\circ} \mathrm{C}$ of dried cheese [26], respectively. From the dry matter value of the cheese (DM), the value of cheese moisture was calculated as follows: 100-DM.

Moreover, starting from the hydrochloric ash solution, the content of $\mathrm{Ca}, \mathrm{Mg}, \mathrm{K}, \mathrm{Na}$ and $P$ of the cheese was determined, with the same methods used for milk and described above. From the value of $\mathrm{Na}$, the cheese salt content $(\mathrm{NaCl})$ was calculated stoichiometrically.

Moreover, for cheese protein, ash, $\mathrm{Ca}, \mathrm{Mg}, \mathrm{K}, \mathrm{Na} \mathrm{P}$ and sodium chloride contents, the values expressed for the dry matter were calculated as follow:

$$
\mathrm{CDM}=\mathrm{CC} \times 100 / \mathrm{DM}
$$

where CDM is the content on a dry matter basis, expressed as $\mathrm{g} / 100 \mathrm{~g}$ of dry matter; CC is the content in the cheese, expressed as $\mathrm{g} / 100 \mathrm{~g}$ cheese; DM is the value of cheese dry matter.

\subsection{Milk and Cheese Microbiological Analyses}

For each FC-milk, V-milk sample and cheese sample, the following microbiological analyses were performed. Microbiological analyses in cheese were performed by plating a diluted suspension of $10 \mathrm{~g}$ of grated cheese in $90 \mathrm{~mL}$ of $20 \%$ trisodium citrate ( $\mathrm{pH} 7.5$ ) [32].

Serial decimal dilutions of each sample in $9 \mathrm{~g} / \mathrm{L} \mathrm{NaCl}$ water were prepared and then plated in duplicate on agar plates. The total mesophilic count was counted on PC Agar (OXOID) incubated at $30^{\circ}$ for $48 \mathrm{~h}$; Lactococci and Streptococci were counted on M17 agar (OXOID) after incubation at 22 and $45^{\circ} \mathrm{C}$, respectively; Lactic acid bacteria (LAB) were counted in MRS agar (OXOID) at $\mathrm{pH}$ between 6.6 and 6.8 in anaerobic jars for 5 days at $22{ }^{\circ} \mathrm{C}$ for mesophilic LAB and at $45^{\circ} \mathrm{C}$ for thermophilic LAB; Enterococci were counted on Slanetz and Bartley agar (OXOID) incubated at $45^{\circ} \mathrm{C}$ for $48 \mathrm{~h}$.

Moreover, the following microbiological analyses were performed for all FC-milk and V-milk samples only:

Fecal coliform bacteria on Violet Red Bile Lactose Agar (OXOID) for $24 \mathrm{~h}$ at $42{ }^{\circ} \mathrm{C}$; Coagulase Negative Cocci (CNC), counted on Mannitol Salt Agar (OXOID) after incubation for $72 \mathrm{~h}$ at $30^{\circ} \mathrm{C}$.

The spores of anaerobic clostridia were determined by the most probable number (MPN) technique. Briefly, aliquots $(10,1$ and $0.1 \mathrm{~mL})$ of samples prepared using sterile Ringer solution were inoculated into 3 tubes containing RCM (OXOID) with or without lactate.

Each tube was overlaid with $1.5 \mathrm{~mL}$ of sterile melted paraffin Vaseline mixture (1:1, $\mathrm{wt} / \mathrm{wt}$ ) and heated at $80{ }^{\circ} \mathrm{C}$ for $10 \mathrm{~min}$ to kill vegetative cells. Incubation was carried out at $37^{\circ} \mathrm{C}$ for 7 days and daily inspected for gas production. The MPN counts were expressed as the number of spores per liters of milk. 


\subsection{Standard Cheese Yield}

The standard cheese yield of milk was determined by applying the methodology developed by Bortolazzo et al. [33], modified as follows, in order to apply it to full-fat raw milk (FC-milk), as well as partially skimmed milk (V-milk).

About $7 \mathrm{~kg}$ of whole milk was heated to $30^{\circ} \mathrm{C}$, the temperature at which natural whey from a Parmigiano Reggiano cheese factory was inoculated in such a concentration to increase acidity to $4.4^{\circ} \mathrm{SH} / 50 \mathrm{~mL}$ (approximately $\mathrm{pH}$ 6.44). Then, the mix was heated to $34^{\circ} \mathrm{C}$ and, when the temperature was reached, calf rennet (Christian Hansen, $1000 \mathrm{IMCU}-$ International Milking Clotting Unit) was added in a concentration of $0.04 \mathrm{IMCU} / \mathrm{kg}$ of milk. The optimal moment to cut the curd after milk coagulation was determined with the aid of Optigraph, an optical instrument that allows monitoring of the coagulation process. The curd was cut into cubes with a side of $0.5 \mathrm{~cm}$. About $3 \mathrm{~min}$ after the cut, whey started to separate from the curd, and the curd was heated until $47^{\circ} \mathrm{C}$ to allow whey separation. Having reached that temperature, the curd was left under the whey for about $30 \mathrm{~min}$. After that time, the curd was retired from the vat and put into a mould of $12 \mathrm{~cm}$ in diameter. The cheese was left in the mould for about $3 \mathrm{~h}$ at $40^{\circ} \mathrm{C}$ with a load of $750 \mathrm{~g}$ on top to facilitate whey draining. After, a sample of cheese was taken, in order to determine the dry matter content, to standardise the yield to $60 \%$ of dry matter.

The standard yield of milk was calculated as follow:

$$
\mathrm{SCY}=(\mathrm{CW} / \mathrm{MW}) \times(\mathrm{DM} / 60) \times 100,
$$

where SCY is the standard cheese yield of the milk, CW is the cheese weight (expressed in $\mathrm{g}$ ), MW is the milk weight (expressed in g), and DM is the cheese dry matter (expressed in $\mathrm{g} / 100 \mathrm{~g})$.

Finally, milk temperature evolution over the test was measured and registered, as well as milk and cheese $\mathrm{pH}$ values.

\subsection{Sensory Analysis}

To define the sensory profile of the cheese samples produced, a Quantitative Descriptive Analysis (QDA) test was applied using a panel of 10 assessors, selected and trained [34]. The test was performed according to the ISO standard method [35] and the activity of sensory analysis was conducted in a controlled environment design [36].

The sensory profile for Parmigiano Reggiano pieces includes 11 descriptors that are better explained in Table 1. Each descriptor was evaluated on a structured continuous scale of 7 points $(1=$ absence of sensation, 7 = greatest intensity of sensation). In addition, there were also 4 compliance scores, introduced in order to facilitate the assessment of the sample's compliance to PDO sensory characteristics, as defined in the PDO Parmigiano Reggiano rules. These scores allowed evaluating the level of defectiveness of the samples and to exclude non-PDO Parmigiano Reggiano cheeses. The minimum acceptable value for each compliance score to the PDO is equal to 3.5, a score lower than 3.5 shows a light irregularity, while a score lower than 2.5 indicates a heavy irregularity, resulting in non-compliance with PDO Parmigiano Reggiano cheese.

\subsection{Statistical Analysis}

The significance of the differences between the theses was tested by analysis of variance, using the general linear model procedure of SPSS (IBM SPSS Statistics vers. 27, Armonk, New York, NY, USA), according to the following model:

$$
Y_{i j k}=\mu+C_{i}+T_{j}+\varepsilon_{i j k},
$$

where $Y_{\mathrm{ijk}}=$ dependent variable; $\mu$ = overall mean; $C_{i}=$ effect of the milking type, AMS or TMP $(i=1,2) ; T_{j}=$ effect of trial $(j=1, \ldots, 6) ; \varepsilon_{i j k}=$ residual error.

Moreover, the significance of the differences was tested by means of Bonferroni. 
Finally, descriptive statistical analysis was performed, also by the procedure of SPSS (IBM SPSS Statistics vers. 27, Armonk, New York, NY, USA), on the data obtained from the sensory analysis for 15-month-ripened cheese samples. The sensory descriptor means were distinguished by Student's $t$-test for independent samples $(\alpha=0.05)$.

Table 1. Sensory attributes used for the sensory evaluation of Parmigiano Reggiano PDO cheese.

\begin{tabular}{|c|c|c|}
\hline Attributes & Modality & Description \\
\hline Colour & Visual & $\begin{array}{c}\text { Intensity of the sample's cheese colour can } \\
\text { range from light straw yellow to intense } \\
\text { straw yellow }\end{array}$ \\
\hline Smell intensity & Olfactory & $\begin{array}{c}\text { The strength of stimulation perceived over } \\
\text { the cheese stick }\end{array}$ \\
\hline Butter's smell & Olfactory & Characteristic smell associated with butter \\
\hline Other smells & Olfactory & $\begin{array}{l}\text { Characteristic smell associated with } \\
\text { propionic, butyric, acid, ammonia, acetic, } \\
\text { pungent in the nose, sour, sulphureus, soap, } \\
\text { mouldy, putrid, rubber and silage }\end{array}$ \\
\hline Butter's aroma & Flavour & Characteristic aroma associated with butter \\
\hline Broth's aroma & Flavour & $\begin{array}{l}\text { Characteristic aroma associated with } \\
\text { meat broth }\end{array}$ \\
\hline Other aroma & Flavour & $\begin{array}{l}\text { Characteristic aroma associated with } \\
\text { propionic, butyric, acid, ammonia, acetic, } \\
\text { pungent in the nose, sour, sulphureus, soap, } \\
\text { mouldy, putrid, rubber and silage }\end{array}$ \\
\hline Pungent & Taste & Taste associated with acetic acid solutions \\
\hline Elasticity & Texture & $\begin{array}{c}\text { Aptitude of cheese sample to regain its initial } \\
\text { thickness after being compressed and } \\
\text { deformed }\end{array}$ \\
\hline Solubility & Texture & $\begin{array}{l}\text { A characteristic that develops when the } \\
\text { cheese sample melts very quickly in the } \\
\text { saliva, without giving a feeling of filling }\end{array}$ \\
\hline Presence of grain & Texture & $\begin{array}{c}\text { Aptitude of the cheese sample to generate } \\
\text { numerous hard rounded grains at the end } \\
\text { of chewing }\end{array}$ \\
\hline
\end{tabular}

\section{Results}

Chemical composition, rennet coagulation properties and microbial counts of herd milk milked with an automatic milking system (AMS-milk) and with a traditional milking parlor (TMP-milk) are shown in Table 2 .

The content of lactose ( $p \leq 0.001$ ), the values of titratable acidity and the clotting time (both with $p \leq 0.05$ ) were higher in AMS-milk compared to the TMP one.

On the other hand, the content of crude protein, whey protein (both with $p \leq 0.01$ ) and casein $(p \leq 0.05)$ were lower in the AMS-milk compared to the TMP-milk.

Furthermore, somatic cells showed a lower, and consequently better, average value in AMS-milk compared to TMP $(p \leq 0.05)$.

As far as the microbiological analyses, although the total microbial count did not show a significant difference between AMS-milk and TMP; fecal coliforms were significantly lower in AMS-milk compared to TMP-milk $(p \leq 0.01)$. However, mesophilic and thermophilic lactic acid bacteria also showed lower average values in AMS-milk compared to TMP-milk $(p \leq 0.001)$. 
Table 2. Least square means of chemical composition parameters, rennet coagulation properties and microbial counts of herd whole milk milked with an automatic milking system (AMS) and with a traditional milking parlor (TMP).

\begin{tabular}{|c|c|c|c|c|c|}
\hline Parameter & Unit & AMS $n^{1}=6$ & $\operatorname{TMP} n^{1}=6$ & $\mathrm{SE}^{2}$ & $p^{3}$ \\
\hline Dry matter & $\mathrm{g} / 100 \mathrm{~g}$ & 13.18 & 12.93 & 0.10 & NS \\
\hline Lactose & $\mathrm{g} / 100 \mathrm{~g}$ & 5.08 & 4.94 & 0.01 & $* * *$ \\
\hline Fat & $\mathrm{g} / 100 \mathrm{~g}$ & 3.81 & 3.71 & 0.04 & NS \\
\hline Crude protein & $\mathrm{g} / 100 \mathrm{~g}$ & 3.41 & 3.50 & 0.01 & $* *$ \\
\hline Casein & $\mathrm{g} / 100 \mathrm{~g}$ & 2.64 & 2.71 & 0.01 & $*$ \\
\hline Casein number & $\mathrm{g} / 100 \mathrm{~g}$ & 77.56 & 77.40 & 0.09 & NS \\
\hline $\mathrm{NPN} \times 6.38$ & $\mathrm{~g} / 100 \mathrm{~g}$ & 0.13 & 0.13 & 0.01 & NS \\
\hline $\mathrm{pH}$ & Value & 6.71 & 6.70 & 0.01 & NS \\
\hline Titratable acidity & ${ }^{\circ} \mathrm{SH} / 50 \mathrm{~mL}$ & 3.50 & 3.45 & 0.02 & $*$ \\
\hline Clotting time (r) & minutes & 19.65 & 19.26 & 0.09 & $*$ \\
\hline Curd firming time $\left(\mathrm{k}_{20}\right)$ & minutes & 3.65 & 3.10 & 0.21 & NS \\
\hline Curd firmness $\left(\mathrm{a}_{30}\right)$ & millimetres & 34.48 & 38.07 & 1.25 & NS \\
\hline Standard cheese yield & $\%$ & 10.39 & 10.61 & 0.08 & NS \\
\hline Optimal cutting time & minutes & 13.39 & 13.20 & 0.39 & NS \\
\hline Somatic cells count & Log cells/mL & 5.12 & 5.34 & 0.05 & $*$ \\
\hline Total microbial count & $\log C F U / m L$ & 3.90 & 4.29 & 0.07 & NS \\
\hline Total mesophilic count & $\log \mathrm{CFU} / \mathrm{mL}$ & 3.57 & 3.95 & 0.16 & NS \\
\hline Fecal coliforms & $\log \mathrm{CFU} / \mathrm{mL}$ & 0.70 & 2.16 & 0.34 & $* *$ \\
\hline Enterococci & $\log \mathrm{CFU} / \mathrm{mL}$ & 1.06 & 1.54 & 0.16 & NS \\
\hline Mesophilic LAB & $\log \mathrm{CFU} / \mathrm{mL}$ & 1.99 & 3.37 & 0.22 & $* * *$ \\
\hline Thermophilic LAB & $\log \mathrm{CFU} / \mathrm{mL}$ & 1.48 & 2.75 & 0.14 & $* * *$ \\
\hline Lactococci & $\log C F U / m L$ & 2.26 & 2.82 & 0.36 & NS \\
\hline Streptococci & $\log \mathrm{CFU} / \mathrm{mL}$ & 2.51 & 2.82 & 0.17 & NS \\
\hline Coagulase negative cocci & $\log \mathrm{CFU} / \mathrm{mL}$ & 2.69 & 2.79 & 0.15 & NS \\
\hline Clostridia spores & Log number/L & 1.53 & 2.14 & 0.11 & NS \\
\hline
\end{tabular}

${ }^{1}$ Number of samples. ${ }^{2}$ Standard error. ${ }^{3} p$-value: NS $p>0.05 ;{ }^{*} p \leq 0.05 ;{ }^{* *} p \leq 0.01 ;{ }^{* * *} p \leq 0.001$.

Moreover, the full-fat herd milk showed differences neither in the standard cheese yield (10.61\% vs. $10.39 \%)$ nor in the optimal cutting time (13.20 min vs. $13.39 \mathrm{~min}$ ) between the two experimental theses.

Minerals contents and salt equilibria of herd milk milked with an automatic milking system and with a traditional milking parlor are shown in Table 3.

Among the mineral compounds, the average contents of ash $(p \leq 0.05)$, of total $(p \leq 0.01)$, soluble $(p \leq 0.001)$ and colloidal calcium $(p \leq 0.05)$, and chloride $(p \leq 0.05)$ were significantly lower in AMS-milk than in TMP-milk.

Chemical composition, rennet coagulation properties and microbial counts of vat milk obtained from herd milk milked with an automatic milking system (AMS-milk) and with a traditional milking parlor (TMP-milk) are shown in Table 4.

From what was observed in the herd milk (FC-milk), in vat milk only the lactose content $(p \leq 0.05)$, the titratable acidity $(p \leq 0.01)$ and the somatic cells count $(p \leq 0.01)$ showed a significant difference between the two theses, the first being two higher, and the third lower in the AMS-milk than in the TMP-milk.

Moreover, vat milk did not show significant differences among cheese yield of AMSmilk $(9.71 \%)$ and TMP-milk (9.72\%) and among the optimal cutting time (13.21 vs. 12.84 min, respectively).

Chemical composition parameters, mineral content and microbial counts of Parmigiano Reggiano cheese ripened for 15 months, obtained from herd milk milked with an automatic milking system and with a traditional milking parlor are shown in Table 5. Not one of the parameters analysed for cheese showed significant differences between the two experimental theses. 
Table 3. The least square means of minerals contents and salt equilibria of herd whole milk milked with an automatic milking system (AMS) and with a traditional milking parlor (TMP).

\begin{tabular}{|c|c|c|c|c|c|}
\hline Parameter & Unit & AMS $n^{1}=6$ & $\operatorname{TMP} n^{1}=6$ & $\mathrm{SE}^{2}$ & $p^{3}$ \\
\hline Ash & $\mathrm{g} / 100 \mathrm{~g}$ & 0.73 & 0.74 & 0.01 & * \\
\hline Total Ca & $\mathrm{mg} / 100 \mathrm{~g}$ & 118.81 & 122.81 & 0.53 & $* *$ \\
\hline Soluble Ca & $\mathrm{mg} / 100 \mathrm{~g}$ & 34.35 & 35.95 & 0.09 & $* * *$ \\
\hline Colloidal Ca & $\mathrm{mg} / 100 \mathrm{~g}$ & 84.45 & 86.85 & 0.46 & $*$ \\
\hline Total P & $\mathrm{mg} / 100 \mathrm{~g}$ & 98.63 & 98.27 & 0.41 & NS \\
\hline Soluble P & $\mathrm{mg} / 100 \mathrm{~g}$ & 47.41 & 47.77 & 0.25 & NS \\
\hline Colloidal P & $\mathrm{mg} / 100 \mathrm{~g}$ & 48.89 & 48.24 & 0.21 & NS \\
\hline Total Mg & $\mathrm{mg} / 100 \mathrm{~g}$ & 10.32 & 10.33 & 0.06 & NS \\
\hline Soluble Mg & $\mathrm{mg} / 100 \mathrm{~g}$ & 7.79 & 7.79 & 0.02 & NS \\
\hline Colloidal Mg & $\mathrm{mg} / 100 \mathrm{~g}$ & 2.53 & 2.55 & 0.05 & NS \\
\hline Soluble $\mathrm{Ca}$ & $\mathrm{g} / 100 \mathrm{~g}$ of $\mathrm{Ca}$ & 28.92 & 29.27 & 0.09 & $*$ \\
\hline Soluble P & $\mathrm{g} / 100 \mathrm{~g}$ of $\mathrm{P}$ & 48.08 & 48.61 & 0.09 & NS \\
\hline Soluble $\mathrm{Mg}$ & $\mathrm{g} / 100 \mathrm{~g}$ of $\mathrm{Mg}$ & 75.46 & 75.37 & 0.33 & NS \\
\hline $\mathrm{Na}$ & $\mathrm{mg} / 100 \mathrm{~g}$ & 49.93 & 50.41 & 0.31 & NS \\
\hline K & $\mathrm{mg} / 100 \mathrm{~g}$ & 161.95 & 162.29 & 0.93 & NS \\
\hline Chloride & $\mathrm{mg} / 100 \mathrm{~g}$ & 86.90 & 90.10 & 0.81 & * \\
\hline
\end{tabular}

${ }^{1}$ Number of samples. ${ }^{2}$ Standard error. ${ }^{3} p$-value: NS $p>0.05 ;{ }^{*} p \leq 0.05 ;{ }^{* *} p \leq 0.01 ;{ }^{* * *} p \leq 0.001$.

Table 4. Least square means of chemical composition parameters, rennet coagulation properties and microbial counts of vat milk obtained from herd milk milked with an automatic milking system (AMS) and with a traditional milking parlor (TMP).

\begin{tabular}{|c|c|c|c|c|c|}
\hline Parameter & Unit & AMS $n^{1}=6$ & $\operatorname{TMP} n^{1}=6$ & $\mathrm{SE}^{2}$ & $p^{3}$ \\
\hline Dry matter & $\mathrm{g} / 100 \mathrm{~g}$ & 12.53 & 12.54 & 0.05 & NS \\
\hline Lactose & $\mathrm{g} / 100 \mathrm{~g}$ & 4.97 & 4.90 & 0.01 & * \\
\hline Fat & $\mathrm{g} / 100 \mathrm{~g}$ & 3.30 & 3.35 & 0.02 & NS \\
\hline Crude protein & $\mathrm{g} / 100 \mathrm{~g}$ & 3.42 & 3.46 & 0.03 & NS \\
\hline Casein & $\mathrm{g} / 100 \mathrm{~g}$ & 2.65 & 2.68 & 0.02 & NS \\
\hline Casein number & $\mathrm{g} / 100 \mathrm{~g}$ & 77.46 & 77.51 & 0.13 & NS \\
\hline NPNx6.38 & $\mathrm{g} / 100 \mathrm{~g}$ & 0.13 & 0.13 & 0.01 & NS \\
\hline Fat to casein ratio & Value & 1.25 & 1.25 & 0.01 & NS \\
\hline $\mathrm{pH}$ & Value & 6.71 & 6.71 & 0.01 & NS \\
\hline Titratable acidity & ${ }^{\circ} \mathrm{SH} / 50 \mathrm{~mL}$ & 3.47 & 3.42 & 0.01 & $* *$ \\
\hline Clotting time (r) & minutes & 20.33 & 20.00 & 0.30 & NS \\
\hline Curd firming time $\left(\mathrm{k}_{20}\right)$ & minutes & 33.46 & 34.01 & 0.72 & NS \\
\hline Curd firmness $\left(\mathrm{a}_{30}\right)$ & millimetres & 4.16 & 4.10 & 0.09 & NS \\
\hline Standard cheese yield & $\%$ & 9.71 & 9.72 & 0.07 & NS \\
\hline Optimal cutting time & minutes & 13.21 & 12.84 & 0.23 & NS \\
\hline Somatic cells count & Log cells/mL & 5.04 & 5.23 & 0.03 & $* *$ \\
\hline Total microbial count & $\log \mathrm{CFU} / \mathrm{mL}$ & 4.37 & 4.51 & 0.07 & NS \\
\hline Total mesophilic count & $\log \mathrm{CFU} / \mathrm{mL}$ & 4.25 & 4.37 & 0.12 & NS \\
\hline Fecal coliforms & $\log \mathrm{CFU} / \mathrm{mL}$ & 2.23 & 2.32 & 0.19 & NS \\
\hline Enterococci & $\log \mathrm{CFU} / \mathrm{mL}$ & 1.58 & 1.63 & 0.41 & NS \\
\hline Mesophilic LAB & $\log \mathrm{CFU} / \mathrm{mL}$ & 3.15 & 3.31 & 0.20 & NS \\
\hline Thermophilic LAB & $\log \mathrm{CFU} / \mathrm{mL}$ & 2.46 & 2.53 & 0.18 & NS \\
\hline Lactococci & $\log \mathrm{CFU} / \mathrm{mL}$ & 3.12 & 2.71 & 0.44 & NS \\
\hline Streptococci & $\log \mathrm{CFU} / \mathrm{mL}$ & 3.41 & 3.47 & 0.17 & NS \\
\hline Coagulase negative cocci & $\log \mathrm{CFU} / \mathrm{mL}$ & 2.82 & 2.97 & 0.10 & NS \\
\hline
\end{tabular}

${ }^{1}$ Number of samples. ${ }^{2}$ Standard error. ${ }^{3} p$-value: NS $p>0.05 ;{ }^{*} p \leq 0.05 ;{ }^{* *} p \leq 0.01$. 
Table 5. Least square means of chemical composition parameters, mineral profile and microbial counts of the Parmigiano Reggiano ripened for 15 months obtained from herd milk milked with an automatic milking system (AMS) and with a traditional milking parlor (TMP).

\begin{tabular}{|c|c|c|c|c|c|c|}
\hline & \multicolumn{3}{|c|}{ AMS $\left(n^{1}=6\right)$} & \multicolumn{3}{|c|}{$\operatorname{TMP}\left(n^{1}=5\right)$} \\
\hline Parameter & Unit & Mean & $\mathrm{SE}^{2}$ & Mean & $\mathrm{SE}^{2}$ & $p^{3}$ \\
\hline \multicolumn{7}{|c|}{ Values expressed on whole cheese: } \\
\hline Moisture & $\mathrm{g} / 100 \mathrm{~g}$ & 31.70 & 0.06 & 31.77 & 0.07 & NS \\
\hline Total $\mathrm{N}$ & $\mathrm{g} / 100 \mathrm{~g}$ & 4.63 & 0.01 & 4.62 & 0.01 & NS \\
\hline Soluble $\mathrm{N}$ at $\mathrm{pH} 4.4$ & $\mathrm{~g} / 100 \mathrm{~g}$ & 1.29 & 0.02 & 1.28 & 0.03 & NS \\
\hline Crude protein & $\mathrm{g} / 100 \mathrm{~g}$ & 27.91 & 0.42 & 27.79 & 0.49 & NS \\
\hline Ripening index & $\%$ & 29.51 & 0.08 & 29.44 & 0.09 & NS \\
\hline Ash & $\mathrm{g} / 100 \mathrm{~g}$ & 4.36 & 0.06 & 4.46 & 0.08 & NS \\
\hline $\mathrm{Ca}$ & $\mathrm{mg} / 100 \mathrm{~g}$ & 984.87 & 3.95 & 996.06 & 4.67 & NS \\
\hline $\mathrm{P}$ & $\mathrm{mg} / 100 \mathrm{~g}$ & 623.28 & 1.94 & 618.93 & 2.30 & NS \\
\hline $\mathrm{Mg}$ & $\mathrm{mg} / 100 \mathrm{~g}$ & 31.11 & 0.92 & 29.74 & 1.08 & NS \\
\hline $\mathrm{Na}$ & $\mathrm{mg} / 100 \mathrm{~g}$ & 660.00 & 6.68 & 668.20 & 7.90 & NS \\
\hline $\mathrm{K}$ & $\mathrm{mg} / 100 \mathrm{~g}$ & 146.75 & 0.94 & 147.41 & 1.11 & NS \\
\hline Salt $(\mathrm{NaCl})$ & $\mathrm{g} / 100 \mathrm{~g}$ & 1.68 & 0.02 & 1.70 & 0.02 & NS \\
\hline Total mesophilic count & $\log C F U / m L$ & 4.95 & 0.21 & 5.33 & 0.19 & NS \\
\hline Enterococci & $\log C F U / m L$ & \multicolumn{2}{|c|}{ Always less than 1} & \multicolumn{2}{|c|}{ Always less than 1} & \\
\hline Mesophilic LAB & $\log C F U / m L$ & 4.71 & 0.13 & 4.85 & 0.42 & NS \\
\hline Thermophilic LAB & $\log \mathrm{CFU} / \mathrm{mL}$ & 4.44 & 0.10 & 4.50 & 0.20 & NS \\
\hline Lactococci & $\log \mathrm{CFU} / \mathrm{mL}$ & \multicolumn{2}{|c|}{ Always less than 1} & \multicolumn{2}{|c|}{ Always less than 1} & \\
\hline Streptococci & $\log C F U / m L$ & \multicolumn{2}{|c|}{ Always less than 1} & \multicolumn{2}{|c|}{ Always less than 1} & \\
\hline \multicolumn{7}{|c|}{ Values expressed on the dry matter: } \\
\hline Crude protein & $\mathrm{g} / 100 \mathrm{~g}$ & 43.20 & 0.14 & 43.15 & 0.17 & NS \\
\hline Ash & $\mathrm{g} / 100 \mathrm{~g}$ & 6.38 & 0.09 & 6.53 & 0.11 & NS \\
\hline $\mathrm{Ca}$ & $\mathrm{mg} / 100 \mathrm{~g}$ & 1441.91 & 5.58 & 1459.79 & 6.60 & NS \\
\hline $\mathrm{P}$ & $\mathrm{mg} / 100 \mathrm{~g}$ & 912.51 & 3.41 & 907.10 & 4.04 & NS \\
\hline $\mathrm{Mg}$ & $\mathrm{mg} / 100 \mathrm{~g}$ & 45.54 & 1.31 & 43.58 & 1.56 & NS \\
\hline $\mathrm{Na}$ & $\mathrm{mg} / 100 \mathrm{~g}$ & 966.28 & 9.95 & 979.32 & 11.77 & NS \\
\hline $\mathrm{K}$ & $\mathrm{mg} / 100 \mathrm{~g}$ & 214.85 & 1.46 & 216.05 & 1.72 & NS \\
\hline Salt $(\mathrm{NaCl})$ & $\mathrm{g} / 100 \mathrm{~g}$ & 2.46 & 0.03 & 2.49 & 0.03 & NS \\
\hline
\end{tabular}

${ }^{1}$ Number of samples. ${ }^{2}$ Standard error. ${ }^{3} p$-value: NS $p>0.05$.

Finally, sensory analysis parameters of Parmigiano Reggiano ripened for 15 months obtained from herd milk milked with an automatic milking system and with a traditional milking parlor are shown in Table 6; only the butter's aroma flavour showed a significant difference among the two experimental theses $(p \leq 0.05)$.

Table 6. The least square means of sensory analysis parameters of the Parmigiano Reggiano ripened for 15 months obtained from herd milk milked with automatic milking system (AMS) and with traditional milking parlor (TMP).

\begin{tabular}{|c|c|c|c|c|c|c|}
\hline & \multicolumn{3}{|c|}{ AMS $\left(n^{1}=6\right)$} & \multicolumn{2}{|c|}{$\operatorname{TMP}\left(n^{1}=5\right)$} & \multirow[b]{2}{*}{$p^{3}$} \\
\hline Parameter & Modality & Mean & $\mathrm{SE}^{2}$ & Mean & $\mathrm{SE}^{2}$ & \\
\hline Colour & Visual & 3.20 & 0.20 & 3.30 & 0.22 & NS \\
\hline Visual aptitude & Visual & 5.50 & 0.20 & 5.50 & 0.18 & NS \\
\hline Smell intensity & Olfactory & 4.80 & 0.16 & 4.80 & 0.18 & NS \\
\hline Butter's aroma & Olfactory & 3.80 & 0.16 & 3.80 & 0.18 & NS \\
\hline Other smells & Olfactory & 2.10 & 0.16 & 2.20 & 0.18 & NS \\
\hline Olfactory aptitude & Olfactory & 5.30 & 0.16 & 5.20 & 0.18 & NS \\
\hline Butter's aroma & Flavour & 4.20 & 0.12 & 4.10 & 0.18 & * \\
\hline Broth's aroma & Flavour & 3.00 & 0.20 & 3.00 & 0.22 & NS \\
\hline Other aroma & Flavour & 2.20 & 0.16 & 2.30 & 0.18 & NS \\
\hline Pungent & Taste & 1.50 & 0.12 & 1.50 & 0.18 & NS \\
\hline $\begin{array}{c}\text { Aroma and flavour } \\
\text { aptitude }\end{array}$ & Taste & 5.20 & 0.16 & 5.20 & 0.22 & NS \\
\hline Elasticity & Texture & 2.50 & 0.16 & 2.60 & 0.18 & NS \\
\hline Solubility & Texture & 4.50 & 0.20 & 4.40 & 0.22 & NS \\
\hline Presence of grain & Texture & 4.00 & 0.20 & 4.00 & 0.22 & NS \\
\hline Texture aptitude & Texture & 5.50 & 0.16 & 5.50 & 0.18 & NS \\
\hline
\end{tabular}

${ }^{1}$ Number of samples. ${ }^{2}$ Standard error. ${ }^{3} p$-value: NS $p>0.05 ;{ }^{*} p \leq 0.05$. 


\section{Discussion}

\subsection{Effect of the Milking System on Herd Milk Characteristics}

The full-fat herd milk milked with AMS was characterised by a higher lactose content and lower somatic cells count compared to the milk milked with TMP.

The average values of somatic cells counts of AMS and TMP milks can be considered low for the first and normal for the second if compared to values that are recorded for the milk destined for Parmigiano Reggiano cheese production. Franceschi et al. [37], for example, in a study conducted on 1080 bulk milk samples, reported average values of somatic cell content, ranging from 209 thousand cells $/ \mathrm{mL}$ (5.32 Log cells $/ \mathrm{mL}$ ) to 253 thousand cells $/ \mathrm{mL}$ (5.40 Log cells $/ \mathrm{mL})$.

However, it should be noted that both average values were lower than the value of 300 thousand cells $/ \mathrm{mL}$ above which there is a reduction in the cheese yield for Parmigiano Reggiano cheesemaking [12], due to the decrease in the cheesemaking efficiency and a consequent increase in the cheesemaking losses $[12,13]$.

The lactose content of AMS-milk was higher than that of TMP-milk, and it was high even if compared with that reported in the literature by Franceschi et al. [38] for milk destined for Parmigiano Reggiano cheese production. They, indeed, report average lactose values ranging from 4.84 to $4.95 \mathrm{~g} / 100 \mathrm{~g}$ for the milk produced by Italian Friesian cows raised in the Parmigiano Reggiano area. The higher lactose content of the AMS-milk is related to the lower content of its somatic cell count.

Indeed, the increase in milk somatic cell count is associated with a mammary gland inflammation process, and the inflammatory response is characterised by an increase in sodium chloride [39,40], that diffuses into the milk directly from blood [41], and by a decrease in the secretory activity of mammary gland, that results in a reduction in milk lactose content $[39,41]$. This observation was confirmed by the milk chloride content that was lower in AMS-milk than in TMP-one.

The lower content of somatic cells of AMS-milk with respect to TMP-milk could be due to a better milking routine of the automatic milking system with respect to one of the milkers, as reported in the literature by many authors $[1,5]$

On the other hand, the full-fat herd milk milked with AMS was characterised by lower crude protein and casein contents than the milk milked with TMP.

Since cheese is formed by a network of paracasein that, during the rennet process, incorporates fat globules and milk whey [42], in Parmigiano Reggiano production the most important factor that affects cheese yield and cheese-making losses is the casein content $[6,7]$.

However, it is important to note that the crude protein and casein average values of both AMS and TMP milk were in agreement with the values recorded by Pretto et al. [43] for milk produced by Italian Friesian cows milked with a traditional milking parlor (3.49 and $2.67 \mathrm{~g} / 100 \mathrm{~g}$, respectively).

However, the higher casein content of the TMP-milk, compared to AMS-milk, corresponded to why the TMP-milk showed higher content of total calcium compared to AMS-milk.

Calcium, indeed, is one of the essential constituents of the casein micelles [44,45]. This observation was confirmed by the higher content of colloidal calcium of TMP-milk compared to AMS-milk.

Furthermore, the full-fat herd milk milked with AMS, compared to the one milked with TMP, was characterised by higher values of titratable acidity and clotting time. Although the difference among the average values of both these parameters was statistically significant, the entity of these differences was only $0.05^{\circ} \mathrm{SH} / 50 \mathrm{~mL}$ and $0.39 \mathrm{~min}$, respectively.

From a microbiological point of view, the full-fat herd milk milked with AMS was characterised by a lower content of fecal coliforms, and mesophilic and thermophilic lactic acid bacteria, compared to the milk milked with TMP.

The lower content of fecal coliforms, mesophilic and thermophilic lactic acid bacteria, of the milk milked with AMS with respect to the TMP-one could be due, to a better milking 
routine of the automatic milking system with respect to one of the milkers. In this case, probably, the automatic milking systems are equipped with automated udder and teat cleaning systems with better performance than simple manual cleaning operations.

However, the use of automatic milking systems did not affect the native microbiota of milk.

Indeed, mean values for fecal coliform, enterococci and mesophilic bacteria of whole milk are in agreement with those reported in other studies carried out in the Parmigiano Reggiano area [46-48].

Finally, the standard cheese yield was higher for both AMS and TMP full-fat herd milk (10.39 and $10.61 \%$ ), compared to vat milk ones (9.71 and 9.72\%). This is mainly due to the higher content of fat of the full-fat herd milk with respect to vat milk, fat which is retained inside of the curd together with moisture.

\subsection{Effect of the Milking System on Vat Milk and Cheese Characteristics}

Similar to full-fat herd milk, vat milk also obtained from the milk milked with AMS was characterised by a higher lactose content, by a lower somatic cells count and by a higher titratable acidity value compared to vat milk obtained from the milk milked with TMP.

The somatic cells counts of both vat milks were lower than the respective values of full-fat milk; this result indicates that in the milk of both theses there was a correct reduction in the somatic cell count during the overnight natural creaming of the milk [49]. This observation is in agreement with that reported by Malacarne et al. [50], that, in a study aimed to evaluate the milk maturation process of milk during Parmigiano Reggiano cheesemaking, an average reduction from 266 thousand cells $/ \mathrm{mL}$ of full-fat milk to 19 thousand cells $/ \mathrm{mL}$ of partially skimmed milk was obtained after the overnight natural creaming of the milk.

Moreover, the values of the present research were congruent with the values of somatic cell content of vat milk, destined to Parmigiano Reggiano cheese production obtained from full-fat milk with less than 400 thousand cells $/ \mathrm{mL}$, as reported by Franceschi et al. [13]. These authors, indeed, reported an average value of 146 thousand cells $/ \mathrm{mL}$ (5.16 Log cells/mL).

Furthermore, vat milk obtained from full-fat herd milk milked with AMS, compared to the one milked with TMP, was characterised by higher values of titratable acidity which is similar to what happens for full-fat milk. In addition, in this case, although the difference among the average values was statistically significant, the entity of the difference, only $0.05^{\circ} \mathrm{SH} / 50 \mathrm{~mL}$, should be considered too small to affect the transformation process to Parmigiano Reggiano cheese.

The difference between vat milk obtained from full-fat herd milk milked with AMS, compared to the one milked with TMP, did not affect the composition of the 15-month ripened cheese.

Indeed, among all the parameters considered, none showed statistically significant differences between the two experimental theses.

Moreover, the contents of moisture, crude protein and salt and the ripening index of the cheeses of both batches are in agreement with the data reported in the literature for 15-month ripened Parmigiano Reggiano cheese. Indeed, Pecorari et al. [51] reported average values of moisture, crude protein and salt of 32.21, 31.99 and $1.45 \mathrm{~g} / 100 \mathrm{~g}$, respectively, for Parmigiano Reggiano ripened from 14 to 16 months. Again, Pecorari et al. [51] also reported an average value of the ripening index of $29.02 \%$.

Furthermore, also among the microbiological parameters, no one showed significant differences between the cheese produced with milk milked with AMS and with TMP, and all parameters of ripened cheese were in agreement with those reported in the literature by Coppola et al. [46] and, more recently, by Coloretti et al. [48].

This observation is very important because it confirms the natural replacement of the starter bacteria of the whey starter by the mesophilic lactic bacteria of full-fat milk, which is typical of the ripening process of the Parmigiano Reggiano cheese. Indeed, in the first phase of cheese ripening, there is a predominance of homofermentative thermophilic lactic 
bacteria that come from the whey starter culture, while in the second phase of ripening, mesophilic LAB from milk predominated [48,52].

Parmigiano Reggiano cheese making is mostly artisanal, made from unstandardised raw milk in which the role of the cheesemaker is crucial. Actually, some steps can be adapted by the cheesemaker to the characteristics of the processed milk, thus reducing the effects on the final product of eventual differences observed between vat milks. For example, the quantity of natural whey starter (NWS) added to the vat milk is not standardised and depends on the values of titratable acidity of the natural whey starter and vat milk. As the titratable acidity values of milk (which is raw milk) and NWS change from one cheesemaking to another, the quantities of NWS added also change from one cheesemaking to another. The final aim is to reach a pH of the mixture (vat milk + natural whey starter) of about 6.3-6.4, respectively [52].

Moreover, it is well known that $\mathrm{pH}$ strongly affects all stages of rennet coagulation and the level of drainage of the curd under whey, with repercussions for the efficiency of the cheesemaking process [7].

Furthermore, the level of drainage under whey has a direct influence on the changes in cheese moisture during salting and ripening and, consequently, on the level of moisture of the final product [16]. Moisture has a strong influence on the exchange of salts and water between brine and cheese during salting and affects the enzymatic activities that take place during ripening that are responsible for the sensorial properties of the cheese (e.g., flavour and texture) $[14,51]$.

\subsection{Effect of the Milking System on Sensory Profile}

The sensory profile of 15-month ripened Parmigiano Reggiano PDO cheese obtained from milk milked with the AMS and TMP differs $(p \leq 0.05)$ only for the butter's aroma flavour.

However, it should be noted that the difference among the mean value resulted in a very small entity, which is difficult to perceive by a non-trained consumer.

It should also be underlined that the cheese made with AMS-milk obtained compliance scores above 3.5 for the 4 categories. This means that cheese made with the milk milked with AMS fully complied with the sensory characteristics expected for the Parmigiano Reggiano cheese PDO and it did not show a higher presence of cheese defects, off-flavours or serious visual defects.

\section{Conclusions}

In general, milking cows with AMS affects milk chemical composition and milk physicochemical properties.

Indeed, herd milk milked with AMS showed, with respect to the TMP one, a higher content of lactose, lower content of casein, higher value of titratable acidity and, also, it showed a slower rennet coagulation time. Moreover, the somatic cells count showed differences between AMS and TMP herd milk and it was lower in the first milk compared to the second.

However, the differences recorded among the milk chemical composition parameters of the milk of the two theses, although statistically significant, were too small to influence the standard cheese yield values.

Likewise, all these differences in the milk chemical characteristics were too small to affect the characteristics of the cheeses, whose chemical composition and their microbiological parameters did not show statistically significant differences between the two theses. This is probably caused by the strong impact of the technological steps in the transformation of milk into Parmigiano Reggiano cheese which, as in other artisanal POD cheese productions, tend to reduce the effect of the variability of the milk characteristics on the characteristics of the cheese. 
This latter observation was confirmed by sensory analysis, which indicated that cheeses made with AMS milk fully complied with the sensory characteristics of Parmigiano Reggiano cheese PDO, as defined by the PDO rules.

Author Contributions: Conceptualisation, E.B., F.C. and A.S.; methodology, P.F. (Piero Franceschi); and A.S.; software, P.F. (Piero Franceschi), F.C., M.M., A.G. and V.M.; validation, A.S., M.M., P.F. (Piero Franceschi), E.B., A.G., V.M. and P.F. (Paolo Formaggioni); formal analysis, P.F. (Piero Franceschi), F.C., E.B., A.G. and V.M.; investigation, P.F. (Paolo Formaggioni), P.F. (Piero Franceschi), M.M., E.B., A.S., F.C., A.G. and V.M.; resources, A.S. and M.M.; data curation, E.B., P.F. (Paolo Formaggioni), P.F. (Piero Franceschi), E.B., F.C. and A.G.; writing—original draft preparation, P.F. (Paolo Formaggioni)., P.F. (Piero Franceschi), M.M., E.B., A.S., F.C., V.M. and A.G.; writing-review and editing, P.F. (Piero Franceschi), F.C. and E.B.; visualisation, P.F. (Piero Franceschi), F.C., E.B. and A.S.; supervision, A.S. and E.B.; project administration, P.F. (Piero Franceschi), A.S. and E.B. All authors have read and agreed to the published version of the manuscript.

Funding: This work was carried out thanks to the contribution of the Rural development program 2014-2020 of the Emilia-Romagna Region, as part of the project "L'impatto delle tecnologie innovative sulla caseificazione del Parmigiano Reggiano" Project number F104 of the focus area 3A operation number 16.2.01.

Institutional Review Board Statement: Not applicable.

Informed Consent Statement: Not applicable.

Data Availability Statement: The data presented in this study are available on request from the corresponding author.

Conflicts of Interest: The authors declare that there are no conflict of interest in this research article.

\section{References}

1. Jacobs, J.A.; Siegford, J.M. Invited review: The impact of automatic milking systems on dairy cow management, behavior, health, and welfare. J. Dairy Sci. 2012, 95, 2227-2247. [CrossRef] [PubMed]

2. Speroni, M.; Pirlo, G.; Lolli, S. Effect of automatic milking systems on milk yield in a hot environment. J. Dairy Sci. 2006, 89, 4687-4693. [CrossRef]

3. Tse, C.; Barkema, H.W.; DeVries, T.J.; Rushen, J.; Pajor, A. 2018 Impact of automatic milking systems on dairy cattle producers' reports of milking labour management, milk production and milk quality. Animal 2018, 12, 2649-2656. [CrossRef] [PubMed]

4. De Marchi, M.; Penasa, M.; Cassandro, M. Comparison between automatic and conventional milking systems for milk coagulation properties and fatty acid composition in commercial dairy herds. Ital. J. Anim. Sci. 2017, 16, 363-370. [CrossRef]

5. Klungel, G.H.; Slaghuis, B.A.; Hogeveen, H. The effect of the introduction of automatic milking systems on milk quality. J. Dairy Sci. 2000, 83, 1998-2003. [CrossRef]

6. Formaggioni, P.; Summer, A.; Malacarne, M.; Franceschi, P.; Mucchetti, G. Italian and Italian-style hard cooked cheeses: Predictive formulas for Parmigiano-Reggiano 24-h cheese yield. Int. Dairy J. 2015, 51, 52-58. [CrossRef]

7. Franceschi, P.; Malacarne, M.; Formaggioni, P.; Cipolat-Gotet, C.; Stocco, G.; Summer, A. Effect of season and factory on cheesemaking efficiency in Parmigiano Reggiano manufacture. Foods 2019, 8, 315. [CrossRef]

8. Council Regulation (EU) No PDO-IT-02202 of 14 November 2016. Off. J European Union of 13 April 2018, C132/17-19. Available online: https: / / eur-lex.europa.eu/legal-content/EN/TXT/PDF/?uri=CELEX:52018XC0413(01) (accessed on 15 November 2021).

9. Kruip, T.A.M.; Morice, H.; Robert, M.; Ouweltjes, W. Robotic milking and its effect on fertility and cell counts. J. Dairy Sci. 2002, 85, 2576-2581. [CrossRef]

10. Hovinen, M.; Rasmussen, M.D.; Pyörälä, S. Udder health of cows changing from tie stalls or free stalls with conventional milking to free stalls with either conventional or automatic milking. J. Dairy Sci. 2009, 92, 3696-3703. [CrossRef] [PubMed]

11. Franceschi, P.; Summer, A.; Sandri, S.; Formaggioni, P.; Malacarne, M.; Mariani, P. Effects of the full cream milk somatic cell content on the characteristics of vat milk in the manufacture of Parmigiano-Reggiano cheese. Vet. Res. Commun. 2009, 33 (Suppl. S1), 281-283. [CrossRef]

12. Summer, A.; Franceschi, P.; Formaggioni, P.; Malacarne, M. Influence of milk somatic cell content on Parmigiano-Reggiano cheese yield. J. Dairy Res. 2015, 82, 222-227. [CrossRef] [PubMed]

13. Franceschi, P.; Faccia, M.; Malacarne, M.; Formaggioni, P.; Summer, A. Quantification of cheese yield reduction in manufacturing Parmigiano Reggiano from milk with non-compliant somatic cells count. Foods 2020, 9, 212. [CrossRef] [PubMed]

14. Malacarne, M.; Summer, A.; Franceschi, P.; Formaggioni, P.; Pecorari, M.; Panari, G.; Mariani, P. Free fatty acid profile of Parmigiano-Reggiano cheese throughout ripening: Comparison between the inner and outer regions of the wheel. Int. Dairy J. 2009, 19, 637-641. [CrossRef] 
15. Sousa, M.J.; Ardo, Y.; McSweeney, P.L.H. Advances in the study of proteolysis during cheese ripening. Int. Dairy J. 2001, 11, 327-345. [CrossRef]

16. Franceschi, P.; Malacarne, M.; Formaggioni, P.; Faccia, M.; Summer, A. Effects of milk storage temperature at the farm on the characteristics of Parmigiano Reggiano cheese: Chemical composition and proteolysis. Animals 2021, 11, 879. [CrossRef] [PubMed]

17. Association of Official Analytical Chemists [AOAC]. Nitrogen (total) in milk, method no. 991.20. In Official Methods of Analysis of AOAC International, 18th ed.; Horowitz, W., Ed.; AOAC International: Gaithersburg, MD, USA, 2005; pp. 10-12.

18. Association of Official Analytical Chemists [AOAC]. Noncasein nitrogen content of milk, method no. 998.05. In Official Methods of Analysis of AOAC International, 18th ed.; Horowitz, W., Ed.; AOAC International: Gaithersburg, MD, USA, 2005 ; pp. 50-51.

19. Association of Official Analytical Chemists [AOAC]. Nonprotein nitrogen in whole milk, method no. 991.21. In Official Methods of Analysis of AOAC International, 18th ed.; Horowitz, W., Ed.; AOAC International: Gaithersburg, MD, USA, 2005; pp. 12-13.

20. Franceschi, P.; Brasca, M.; Malacarne, M.; Formaggioni, P.; Faccia, M.; Natrella, G.; Summer, A. Effects of the cooling temperature at the farm on milk maturation and cheesemaking process in the manufacture of Parmigiano Reggiano PDO Cheese. Animals 2021, 11, 2835. [CrossRef] [PubMed]

21. International Dairy Federation Standard 141/ISO9622; Milk and Liquid Milk Products, Guidelines for the Application of Mid-Infrared Spectrometry. International Dairy Federation: Brussels, Belgium, 2013.

22. Petrera, F.; Catillo, G.; Napolitano, F.; Malacarne, M.; Franceschi, P.; Summer, A.; Abeni, F. New insights into the quality characteristics of milk from Modenese breed compared with Italian Friesian. Ital. J. Anim. Sci. 2016, 15, 559-567. [CrossRef]

23. McMahon, D.J.; Brown, R.J. Evaluation of Formagraph for comparing rennet solutions. J. Dairy Sci. 1982, 65, 1639-1642. [CrossRef]

24. International Dairy Federation Standard 148-2/ISO13366-2; Milk, Enumeration of Somatic Cells, Part. 2: Guidance on the Operation of Fluoro-Opto-Electronic Counters. International Dairy Federation: Brussels, Belgium, 2006.

25. ISO 6731:2010; Milk, Cream and Evaporated Milk e Determination of Total Solids Content. International Organisation for Standardisation: Geneva, Switzerland, 2010.

26. IDF Standard, N 27; FIL/IDF. Determination of Ash Content of Processed Cheese Product. International Dairy Federation: Brussels, Belgium, 1964.

27. Malacarne, M.; Criscione, A.; Franceschi, P.; Tumino, S.; Bordonaro, S.; Di Frangia, F.; Marletta, D.; Summer, A. Distribution of Ca, $\mathrm{P}$ and $\mathrm{Mg}$ and casein micelle mineralisation in donkey milk from the second to ninth month of lactation. Int. Dairy J. 2017, 66, 1-5. [CrossRef]

28. Malacarne, M.; Criscione, A.; Franceschi, P.; Bordonaro, S.; Formaggioni, P.; Marletta, D.; Summer, A. New insights into chemical and mineral composition of donkey milk throughout nine months of lactation. Animals 2019, 9, 1161. [CrossRef]

29. Malacarne, M.; Franceschi, P.; Formaggioni, P.; Pisani, G.M.; Petrera, F.; Abeni, F.; Soffiantini, C.S.; Summer, A. Mineral content and distribution in milk from red deer (Cervus elaphus) fallow deer (Dama dama) and roe deer (Capreolus capreolus). Small Rumin. Res. 2015, 13, 208-215. [CrossRef]

30. International Dairy Federation Standard 88/ISO5943; Cheese and Processed Cheese Products, Determination of Chloride Content, Potentiometric Titration Method. International Dairy Federation: Brussels, Belgium, 2006.

31. Gripon, J.C.; Desmazeaud, M.J.; Le Bars, D.; Bergère, J.L. Study of the role of microorganisms and enzymes in cheese ripening. II. Influence of commercial pressure. Lait 1975, 55, 502-516. [CrossRef]

32. International Dairy Federation Standard 122/ISO/8261; IDF Technical Specification. Milk and Milk Product-General Guidance for the Preparation of Test Samples Initial Suspension and Decimal Dilutions for Microbiological Examination. IDF Standard: Brussels, Belgium, 2001.

33. Bortolazzo, E.; Musi, V.; Vecchia, P. Development of a working protocol for the study of dairy processes and products based on a small-scale experimental plant. Sci. Tec. Latt.-Casearia 2015, 65, 131-132.

34. ISO Standard Number 8586:2014; Sensory Analysis-General Guidelines for the Selection, Training and Monitoring of Selected Assessors and Expert Sensory Assessors. International Organisation for Standardisation: Geneva, Switzerland, 2014.

35. ISO Standard Number 13299:2016; Sensory Analysis-Methodology-General Guidance for Establishing a Sensory Profile. International Organisation for Standardisation: Geneva, Switzerland, 2016.

36. ISO Standard Number 8589:2017; Sensory Analysis-General Guidance for the Design of Test Rooms. Organisation for Standardisation: Geneva, Switzerland, 2017.

37. Franceschi, P.; Malacarne, M.; Formaggioni, P.; Righi, F.; Summer, A. Chemical composition, hygiene characteristics, and coagulation aptitude of milk for Parmigiano Reggiano cheese from farms yielding different milk levels. Rev. Bras. Zootec. 2020, 49, e20180113. [CrossRef]

38. Franceschi, P.; Malacarne, M.; Formaggioni, P.; Faccia, M.; Summer, A. Quantification of the effect of the cattle breed on milk cheese yield: Comparison between Italian Brown Swiss and Italian Friesian. Animals 2020, 10, 1331. [CrossRef]

39. Urech, E.; Puhan, Z.; Schällibaum, M. Changes in milk protein fraction as affected by subclinical mastitis. J. Dairy Sci. 1999, 82, 2402-2411. [CrossRef]

40. Summer, A.; Franceschi, P.; Malacarne, M.; Formaggioni, P.; Tosi, F.; Tedeschi, G.; Mariani, P. Influence of somatic cell count on mineral content and salt equilibria of milk. Ital. J. Anim. Sci. 2009, 8 (Suppl. S2), 435-437. [CrossRef]

41. Somers, J.; O'Brien, B.; Meany, W.; Kelly, A.L. Heterogeneity of proteolytic enzyme activities in milk samples of different somatic cell count. J. Dairy Res. 2003, 70, 45-50. [CrossRef] 
42. Franceschi, P.; Malacarne, M.; Faccia, M.; Rossoni, A.; Santus, E.; Formaggioni, P.; Summer, A. New insights of cheese yield capacity between Italian Brown and Italian Friesian milks in the production of high moisture mozzarella. Food Technol. Biotechnol. 2020, 58, 91-97. [CrossRef]

43. Pretto, D.; De Marchi, M.; Penasa, M.; Cassandro, M. Effect of milk composition and coagulation traits on Grana Padano cheese yield under field conditions. J. Dairy Res. 2013, 80, 1-5. [CrossRef]

44. Gaucheron, F. The minerals of milk. Reprod. Nutr. Dev. 2005, 45, 473-483. [CrossRef] [PubMed]

45. Malacarne, M.; Franceschi, P.; Formaggioni, P.; Sandri, S.; Mariani, P.; Summer, A. Influence of micellar calcium and phosphorus on rennet coagulation properties of cows milk. J. Dairy Res. 2014, 81, 129-136. [CrossRef]

46. Coppola, R.; Nanni, M.; Iorizzo, M.; Sorrentino, A.; Sorrentino, E.; Chiavari, C.; Grazia, L. Microbiological characteristics of Parmigiano Reggiano cheese during the cheesemaking and the first months of the ripening. Lait 2000, 80, 479-490. [CrossRef]

47. Summer, A.; Franceschi, P.; Formaggioni, P.; Malacarne, M. Characteristics of raw milk produced by free-stall or tie-stall cattle herds in the Parmigiano-Reggiano cheese production area. Dairy Sci. Technol. 2014, 94, 581-590. [CrossRef]

48. Coloretti, F.; Chiavari, C.; Nocetti, M.; Reverberi, P.; Bortolazzo, E.; Musi, V.; Grazia, L. Whey starter addition during maturation of evening milk: Effects on some characteristics of cheese milk and Parmigiano-Reggiano cheese. Dairy Sci. Technol. 2016, 96, 185-197. [CrossRef]

49. Ma, Y.; Barbano, D.M. Gravity separation of raw bovine milk: Fat globule size distribution and fat content of milk fractions. J. Dairy Sci. 2000, 83, 1719-1727. [CrossRef]

50. Malacarne, M.; Summer, A.; Formaggioni, P.; Franceschi, P.; Sandri, S.; Pecorari, M.; Vecchia, P.; Mariani, P. Dairy maturation of milk used in the manufacture of Parmigiano-Reggiano cheese: Effects on chemical characteristics, rennet coagulation aptitude and rheological properties. J. Dairy Res. 2008, 75, 218-224. [CrossRef] [PubMed]

51. Pecorari, M.; Fossa, E.; Sandri, S.; Mariani, P. Trend of proteolysis during the ripening of Parmigiano-Reggiano. Sci. Tec. Latt.-Casearia 1997, 48, 61-72.

52. Gatti, M.; Bottari, B.; Lazzi, C.; Neviani, E.; Mucchetti, G. Microbial evolution in raw milk, long ripened cheeses produced using undefined natural whey starters. J. Dairy Sci. 2014, 97, 573-591. [CrossRef] 